\title{
The Effectiveness of Project-Based Learning in Developing English Oral Communication Skills of Secondary Stage Students
}

\author{
Rasha Mohamed Naguib El-Sayed \\ An English Teacher at Port Said Gov. Language School \\ Dr.Jehan Mahmoud El-Bassuony \\ Professor of Curriculum \& Instruction (EFL), Faculty of Education, Port Said \\ University \\ Dr. Walaa Mohamed El-Henawy \\ Lecturer of Curriculum \& Instruction (EFL), Faculty of Education, Port Said \\ University
}




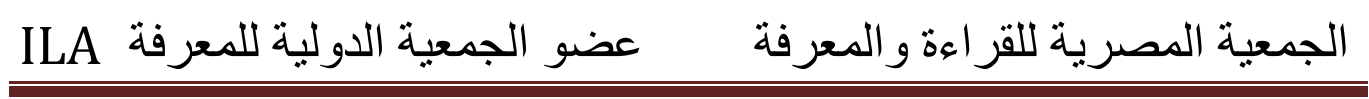




\begin{abstract}
Project-Based learning as a motivating instructional method that places students at the core of the teaching. It is a curriculum-based work/profile which needs collaborative work between learners inside and outside the classroom to collect data, to perform research and produce a certain product. The purpose of this study was to investigate the effectiveness of project-based learning in developing English oral communication skills of secondary stage students. The quasi- experimental design was adopted. The participants were two groups which were randomly chosen and assigned to an experimental group (30) from Port Said Governmental Language School and a control group (30) from Abu Bakr Governmental Language School. The English oral communication skills test was developed and administered for collecting data. Descriptive statistics, the t- test and the Cronbach's Alpha coefficient were used for data analysis. The results revealed that project-based learning was effective in developing English oral communication skills of secondary stage students.
\end{abstract}

Keywords: Project-based learning (PBL), oral communication skills.

\title{
1. Introduction
}

Learners need to be able to keep up with the changes and the speed developments in information technology and the different information resources. Thus, it is important to learn English which is the first international language now due to sociable and cultural aspects and to be able to communicate with others. Oral communication has two types of skills: verbal and non-verbal skills. Oral communication skills are speaking, listening and non-verbal skills (Peterson \& Leonhardt, 2015; Morreale, Spitzberg \& Barge, 2007; Zuheer, 2008). 
Project Based Learning (PBL) is one of the approaches that focuses on teaching through involving students in the investigation. Maulany (2013, p. 33) found out that implementing PBL in teaching English as a Foreign Language made students actively engage in project learning. Also, it enhanced the students' interest, motivation, engagement, and enjoyment. It encouraged social learning that could increase collaborative skills. In addition, Baş (2011, p. 2) revealed that PBL improved the quality of learning and led to higher-level cognitive development through the students' engagement with complex and novel problems.

The present study was designed to investigate the effectiveness of a designed program using project-based learning on students' English oral communication skills. The first author as a teacher observed that the students are unwilling to participate in discussion and tasks that require oral communication. They do not have the ability or the motivation to learn English. Most students complained about getting no feedback about their oral communication skills. In fact, there are many internal and external factors that attribute to students' demotivation to communicate orally or to learn English. The internal factors include students' attitudes towards English, their experiences of failure or lack of success, and incidents related to their self-esteem; the external factors consist of teacher-related factors and the learning environment.

\section{Context of the problem}

Oral Communication skills are important skills for EFL students to master. Previous research has focused largely on the English four skills; however, little is known regarding the oral communication skills of EFL secondary level students, particularly in the Egyptian context. Evidence of the problem was identified through a pilot study that aimed at examining first secondary stage students' oral communication skills. An oral communication skills 
test was administered to first year secondary stage students in Port Said Official Language School. The test was conducted on a group of 32 students. Results indicated that a lot of students were weak in their oral communication skills. They needed to develop many oral communication skills.

In the light of reviewing the related literature and the pilot study, the problem of the present study can be identified in weakness in English oral communication skills of the first year language official secondary students. Therefore, the present study sought to find answers to the main question:

How effective is project-based learning in developing English oral communication skills of secondary stage students? The above main question was investigated through the following sub-questions:

1. What are the English oral communication skills that secondary stage students need to have?

2. What are the features of a treatment using project-based learning in developing the English oral communication skills of secondary stage students?

3. How far is project-based learning effective in developing English oral communication of secondary stage students?

\section{Review of Literature}

\section{Oral Communication Skills}

English becomes the main language of international communication and it is used for intra-national purposes. With globalization, English earns the role of the main language of international communication, increasingly it is also used for intranational purposes. It becomes compulsory at all educational levels, whether formal or informal. Oral communication is the skill that the students will be judged upon most in real-life situation. Many researchers used various definitions of oral communication skills. For example, Morreale, Spitzberg and Barge (2007, p.21 - 42) define 
communication as "a process of managing messages for the purpose of creating meaning". Communication happens in two basic forms verbal and nonverbal). Peterson and Leonhardt (2015, p. 79) describe nonverbal communication or "body language" as silent messages without words where communicators use actions involving posture, facial expressions, the distance between communicators, arm movements, hand movements, placement of the legs and feet, handshakes, and other related behaviors. Mahmoud (2010) describes communication skills as the group of skills that makes a person able to enable a person to transmit information so that it is received and understood. They include verbal / oral, interpersonal and physical skills. In addition to that, they mean using the language appropriately in social interactions and the ability to express basic language functions in order to use language in intended purpose.

Researchers have different views on the components of oral communication skills. There are some researchers who classify oral communication skills into listening and speaking only (e.g. Shabaan, 2010; Khalil, 2015; Hassan, 2018). On the other hand, other researchers (e.g. Zuheer, 2008; Mahmoud, 2010; Hietala, 2013) and this research classify it into verbal and non- verbal skills. According to Rahman (2010, p. 1), oral communication has a number of general and specific instructional functions. Speaking provides the students with a group of skills in their everyday lives to express opinions in presentations, discussions, etc. Moreover, Liao (2009, p.11) declares that listening has some positive effects on developing students' oral English and that students' listening is related to speaking ability. Moreover, Hietala (2013, p. 20) state that the main aim of teaching a foreign language is not only to enable the students to speak but also to enable them to communicate with others. She mentions the factors like grammar, vocabulary, pronunciation, and fluency (confidence) influence oral communication skills. She classifies the skills into production skills, comprehension skills and interaction skills. Moreover, Khalil (2015, p. 39) declares that speaking skills include the following skills: 
Phonological Skills (Uttering English Sounds correctly -Using 1. stress in words-Using intonation patterns correctly).

Grammatical Skills (Using grammatically correct and simple 2 . spoken sentences).

Fluency Skills (Producing simple sentences at a normal rate, 3.

Using hesitation and repetition normally).

Communicative and Discourse Skills by doing the following 4 . communicative functions effectively:

- Descriptions

- Asking questions

- Giving advice and recommendation

- Suggesting solutions

- Expressing opinions

Hietala $(2013,19)$ states that listening and participating means giving (listener) and interpreting (speaker) feedback through words and gestures. Also, Amin, Aly and Amin (2011, p.14) define listening comprehension as a complex process where listeners are able to use the given information whether in the oral text or spoken language to guess and understand the meaning of the new items and predict outcomes. Moreover, Khalil (2015, p. 37) suggests that listening skills are as follows:

Identifying the main idea of the spoken text 1 . Identifying specific information of the spoken text 2 . Identifying more details about the spoken text 3 . Identifying cause and effect relationships in the spoken text 4 . Anticipating the meaning of unknown words or phrases in the 5 . spoken text

Understanding the difference between facts and opinions in the 6 . spoken text

Distinguishing between important and unimportant information 7. Drawing Conclusions, inferences and predictions. 8 . 
Hietala (2013, p. 18) shows that the feedback given by the listeners can be verbally or non-verbally to enhance the speaker to continue communicated. The feedback can be some paralinguistic features whether eye, some facial expressions or affirmative sounds and words (really, mmm, oh). Furthermore, Zoric and Pandzic (2007, p.3) assert that non-verbal communication means any kind of message exchange without using words. Non-verbal communication can be classified into:

1. Kinesics (body language). It refers to body movements including facial expressions, eye movements, gestures, posture, etc.

2. Oculesics (eye contact). Eye contact is very effective on the perceived message.

3. Haptics (touch). The touching behavior which people use to interact.

4. Proxemics (proximity). Personal space is considered.

5. Paralanguage (paralinguistics). The non-verbal language that is used.

6. Chronemics. Timing of verbalizations and pauses.

7. Silence. Verbal and non-verbal cues is not exist.

8. Olfactics (smell).

9. Vocalics (vocal features of speech). The tone of voice, volume and the speed of speech.

10.Physical appearance. Body characteristics, clothing, etc....

11. Symbolism. Signs and symbols meaning.

It is an important part of everyday interaction and most often the first impression of a person is based on his/her ability to speak fluently and comprehensibly.So, teachers have a responsibility to prepare the students as much as possible to be able to speak English in the real world outside the classroom and the testing room. According to Rahman (2010, p. 1), oral communication fulfills a number of general and discipline-specific pedagogical functions. Learning to speak is an important goal in itself, for it equips students with a set of skills they can use for the rest of their lives. 
Furthermore, Caspersz and Stasinska (2015, p.1) state that listening is important to learning as well as enhancing the employment opportunities for undergraduates. It plays a role in the everyday development and maintenance of social and personal relationships. It is a key skill in fostering collaborative learning. Moreover, Liao (2009, p.11) declare that job candidates need to communicate with international managers and they must be able to express themselves accurately and clearly. Nevertheless, it is affirmed that listening has some positive effects on improving students' oral English and that there is a relation between students' listening and speaking ability. Though the importance of oral communication skills, a number of studies (Chelbi, 2010 ; Abd El-kader, 2018; Abd ElKhalek 2018) shed light on the low level of students' English oral communication skills in different educational stages. Hamad (2013, p. 87-88) states that oral communication skills are usually neglected in classrooms and this is clear in student's lack of ability to speak fluently or speak orally. There are factors that negatively affect speaking skills and students' proficiency such as using Arabic in class, structure-oriented instruction and using materials that do not encourage students to communicate orally.

Several studies have been conducted to enhance the oral communication skills of EFL students. For example, Abd El-Khalek (2018) used a program based on compensation strategies to overcome young learners' oral communication difficulties. Abd Elkader (2018) developed EFL students' oral performance through using some kinesthetic activities. In addition, Chelbi (2010) used communicative language teaching as a method to motivate 80 students to perform better orally. These studies mentioned that the reasons of that problem could be the methods of teaching oral communication skills and also students' lack of motivation to learn English. Shabaan (2010) studied the effectiveness of a suggested computer-based program for developing some EFL oral communication skills appropriate for 39 students of first year preparatory school. Aslo, Iamsaard and Kerdpol (2015) used 
dramatic activities for improving English communicative skills of eleventh graders.

To sum up, oral communication skills are very important means of communicating verbal or non-verbal messages that the speaker wants to send or transmit to the listener. They are a set of skills that involve various pedagogical functions. In fact, students need to speak and express themselves freely without being reluctant. On the other hand, there are many elements that affect students' oral communication skills and hinder them to use the target language in authentic contexts. According to the previously mentioned studies, oral communication skills should be enhanced. All of these studies developed the oral communication skills of their students by using different pedagogical approaches. Students should be motivated to communicate orally and to get rid of their anxiety while using the language. On these grounds, it becomes evident that there is a need to use a stimulating and flexible approach, such as Project-based learning, that allows learners to work cooperatively with meaningful experience in an authentic context.

\section{Project- based Learning}

There are many studies that handled the theoretical basis of project-based learning. Simpson (2011, p.24) claims that the theoretical basis of project-based learning is constructivism where it believes that the learner should construct knowledge. The development of mind is considered as a balance between the previous knowledge and the current experience. John Dewey believes that the goal of education is a kind of preparing the learner to participate in social and political life. He thinks that learning is an adaptive process. Constructivism engages students in active, intentional, authentic, reflective and social-dialogical learning. Also, Ilter (2014, p.448-449) added that the constructivist approaches work to develop academic motivation and achievement to develop cognitive skills in a wide variety in class participation on 


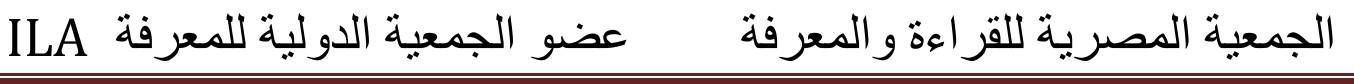

social studies. PBL creates atmospheres that give the learners a chance to feel that they are the owner of a project and become highly motivated.

There are many definitions of PBL. For instance, Fragoulis (2009, p.113) defines the project method as a natural expansion of what is already occurring in class. Also, Simpson (2011, p.41) describes PBL as a comprehensive learning concentrating on authentic problems and challenges that let students work on meaningful collaborative activities resulting in an end product. In addition, Mitry (2009, p.27) describes the project-based approach as an instructional method with integral tasks that interrelate all language skills and focuses on themes of interest. It is a curriculumbased work/profile which needs collaborative work between learners inside and outside the classroom to collect data, to perform research and produce a certain product to enhance Applied Arts students' technical writing skills and genres.

Furthermore, PBL is an approach that emphasizes meaningful learning long term interdisciplinary, and student-centered activities. These learning activities is designed to provide students with real world relevance, complex tasks, and creative outcomes. This can give the students opportunities to master course content and objectives, select their own learning tools (Soparat, Arnold, \& Klaysom, 2015, p.11).

As PBL is an important pedagogical approach, it has some features and characteristics. The characteristics of the project-based learning are as follows: students can become creative and communicative and choose the activities and work during the course of the study. The students are depending on their knowledge in their everyday life; the project-based learning connects manual and intellectual work. In addition, projects correlate between learners' prior experience and new knowledge, they become self-directed and motivated, as students are responsible for their learning, and they use different ways of communication and presentation (English \& Kitsantas, 2013; Filippatou \& Kaldi, 2010, p.17). 
Besides, some features of PBL are as follows: developing students' ability to make long-term plans and successfully manage their time; reflective diaries give students an opportunity to practice writing skills that can be broadly applied at any workplace as at the beginning of the project, students have to go through the stage of getting used to keep a reflective diary as part of PBL course needs; in PBL classroom environment, the emphasis changes from exams and grades toward self-motivated, lifelong learning where students are provoked to question the unknown, use critical thinking, compare and contrast, and draw their own conclusions; in PBL classes the term self-discovery is known for the first time in students' lives where it directs them to reshape their vision, reorganize priorities and goals, improve their self-confidence, and develop their horizons (Dauletova, 2014, p. 186-187).

Furthermore, Shehata (2015) examined the effectiveness of using PBL integrated with ICT in enhancing the oral skills of 50 pupils in the second year preparatory School, Minia governorate. The instruments involved a needs assessment checklist of listening and speaking skills, Teacher's survey on the techniques teachers used in teaching English, communicative Speaking Test and communicative Listening Test. The first author found that most of the PBL integrated with ICT participants achieved significantly higher levels in their oral communication skills than those of the non-treatment group on post-tests.

There are main stages when applying any project. The present study follows Fragoulis' model of project work. Fragoulis (2009, p. 114) and Maulany (2013, p. 32-33) state that the following are the stages that can be used for the successful implementation of project work:

Stage 1. Speculation: In this stage the students choose the project topic according to their interest and developing a climate conductive to speculation and investigation that will lead easily to the research process. Topic is chosen after a dialogue among all members of the group, and the teacher. The initial motive may come from the 
curriculum, or after a discussion about a current local or wider topic of interest, or from reading a newspaper or magazine article.

Stage 2. Designing the project activities: This stage includes assigning groups and roles, decisions concerning methodology, sources of information, activities that will take place, and places outside the classroom that students will visit. Whenever the activities are better organized, the structure of the activities is more analytical and the research will be conducted easily and fast.

Stage 3. Conducting the project activities: At this stage the groups cooperate to implement the activities designed in the previous stage. Students gather information, process and categorize it. The final products are shown in the school or the wider community, and become a stimulus for thought and action for other students, teachers and local community. The project connects the school with the community and real life.

Stage 4. Evaluation: This stage includes the assessment of the activities, the final product and the experience that the students get. There can be recognition of problems or an appraisal of the rich collected material.

In fact, the classroom environment becomes a rehearsal where the variety of final tasks in foreign language teaching is the component to prepare learners to use English in the world beyond the classroom. Using different materials in the activities will allow learners to experiment with the roles they use in real life.

\section{Methodology}

\section{Participants of the study}

The current study targeted first secondary stage students. A classroom that included 30 students was selected as the experimental group at Port Said Official language school the first semester of academic year $2017 / 2018$. Another classroom that also included 30 students at the first secondary stage was selected 
randomly from Abu Bakr Official language school as a control group. Their age ranged from 15 to 16 years old.

\section{Instrument of the study}

The oral communication skills pre-post-test was designed to assess students' English oral communication skills in the light of a list of oral communication skills. This list was designed to identify verbal and nonverbal skills required for first year students of the secondary stage. The skills list is based on the objectives included in The National Curriculum Framework for English as a Foreign Language (EFL) 2011-2012, the teacher's guide of "Hello! English" for first secondary stage (2016-2017), the student's text book as well as literature review and related studies. The skills list contains two types of skills as follows:

The verbal communication skills which include: A.

1. Identify the main idea of the spoken text

2. recognize specific information of the spoken text

3. Predict the meaning of unknown words or phrases in the spoken text

4. Recognize the communicative function of utterances in spoken Language

5. Identify reduced forms of words in spoken language

6. Identify the idea of a given speech

7. Identify the meaning through intonation

8. Draw conclusions related to the feelings of the speaker.

9. Pronounce English Sounds correctly

10.Use word stress appropriately

11.Describe people, objects and places

12.Reflect simple ideas

13.Ask for and give advice

The nonverbal communication skills which include: $B$.

1. Make use of facial, paralinguistic clues to work out meanings. 
2. Use smiling as non-verbal feedback.

3. Give a response using nodding.

4. Maintain eye contact throughout the Conversation.

5. Change intonation and the speed of speech to convey a certain message.

6. Have balanced posture when speaking.

7. Recognize when to be silent.

8. Use body movements that are free of distracting movements such as nervous gestures (touching hair/glasses).

The skills list was prepared in the form of a questionnaire for rating the degree of importance of each skill which is determined on the basis of 4 scores. The first level (very important) is given 4 scores, the second level (important) is given 3 scores, the third level (less important) is given 2 scores and the fourth level (not important) is given 1 score. The questionnaire was presented to 12 TEFL specialists to evaluate the selected skills in terms of the importance of each skill for the first secondary stage students. According to the jurors' opinion on the oral communication skills, the first authors divided the skills to be verbal and nonverbal instead of speaking, listening and interaction skills.

The oral communication skills test consists of two major parts:

part one tackles the speaking part and part two tackles the listening part.

Part one. The pre-post speaking part: This part was administered to the experimental group before starting the treatment to make sure that any progress in the experimental group students' speaking skills could be attributed to the implementation of the treatment. The speaking part aims at evaluating the student's ability to:

1. Present simple ideas.

2. Pronounce English Sounds correctly.

3. Use word stress appropriately. 
4. Change intonation and the speed of speech to convey a certain message.

5. Predict the meaning of unknown words or phrases in the spoken text

6. Recognize the communicative function of utterances in spoken Language

7. Identify reduced forms of words in spoken language

8. Draw conclusions related to the feelings of the speaker.

Part Two. The pre-post listening part: The purpose of the listening part, in this study, aims at evaluating the student's ability to:

1. Identify the main idea of the spoken text

2. recognize specific information of the spoken text

3. Predict the meaning of unknown words or phrases in the spoken text

4. Recognize the communicative function of utterances in spoken Language

5. Identify reduced forms of words in spoken language

6. Identify the idea of a given speech

7. Identify the meaning through intonation

8. Draw conclusions related to the feelings of the speaker.

A scoring rubric was developed for assessing student's speaking skills. The rubric consisted of four levels from 1 to 4 . Scoring focuses on assessing students' verbal skills. The best performance is given 4 and the worst one is given 1. As for the listening skills part. Twelve scores for the test, a mark for each question. On the other hand, the nonverbal skills were evaluated through observing students' performance by using a rating scale. The teacher observed the student while answering the speaking questions and tick any of the following items (never, rarely, sometimes or often) that express the student's nonverbal skill.

The test was submitted to two TEFL professors, assistant professors and three TEFL supervisors to evaluate the validity of the 
test in terms of (a) the appropriateness of the tasks to the measured verbal skills and the student's level, (b) the suitability of its content (pictures, topics, situations) to the student's level, (c) the appropriateness of the number of test items as a whole and as specified for verbal skills (listening and speaking skills). To ensure the reliability of the verbal skills rubric, the inter-rater reliability coefficient was estimated and it was 0.512 and significant at the level 0.01 . To ensure the Inter-rater reliability of the nonverbal skills rating scale the inter-rater reliability coefficient was estimated and it was 0.683 and significant at the level 0.01 .

\section{Treatment}

The aim of this treatment was defined based on the review of literature and related studies on the one hand and results of the pilot study on the other hand. Thus, the major goal of the program was developing first year secondary official school students' English oral communication skills. This goal was translated into the following specific objectives:

1. Identify the main idea of an auditory text.

2. Recognize supporting ideas.

3. Utter English Sounds correctly.

4. Use stress and intonation patterns correctly.

5. Produce simple sentences.

6. Use vocabulary appropriately.

7. Use the correct forms of tenses.

8. Speak in public.

9. Act a role in a play.

10.Identify the speaker's attitude to the listener or the subject of the discussion.

11.Draw correct conclusions about the situation or the general context.

12.Recognize the speaker's purpose. 
The experimental group received 10 instructional sessions in the first term and each session lasted for 45 minutes. Sometimes lessons were divided over multiple meeting sessions. Some sessions were repeated until reaching the required performance. The topics were selected according to students' interests. The students selected three projects to do. The first project was acting a play about Oliver Twist. The preparation of the project took three sessions. As for the second project, it was about designing a survey to find the best ways to memorize the information they need and recall it easily. The students wrote the result of this survey. It took three sessions to be fulfilled. Then, they presented it in the English broadcast. Finally, the last project was a debate about the pros and cons of living in the city or countryside. It takes three sessions to be fulfilled.

Since PBL is a learner centered approach, students were encouraged to be active as well as positive learners. They had to work individually as well as in groups. They were asked to design three projects. They worked hard to act the play and to design the costumes. They had a pioneering role in assigning the roles and practised a lot in the rehearsals. As for the second project, they interviewed the professors of Educational psychology at the faculty of Education and designed a survey on the best ways of studying and recalling information. In addition, they worked collaboratively to make the debate entitled "living on in the city or the countryside". So, they had the opportunity to use language in a natural context. Their autonomy was improved. Also, they developed their confidence and independence.

At the end of each project, the teacher asked the students to reflect on what they did in their project. The teacher recorded their reflections as a way to develop their English oral communication skills. Also, the final product was evaluated by an individual student, students as a group, a teacher or people who watched the project. Students had to present and apply what they have learnt. As for the 
play project, it was presented on a stage and the school administration and some of the officials in the Port Said Governorate watched it. Both formative and summative evaluations were used as follows: (a) Formative assessment was used to conduct in-process evaluations of student comprehension, learning needs, and academic progress during each session in the treatment. Formative assessments helped the teacher to identify concepts that students were struggling to understand, skills they are having difficulty acquiring to make the required adjustments. At the end of each session there were different techniques to evaluate students' performance such as answering oral questions and recording oral reflections. (b) Summative assessment was conducted at the end of the treatment through using the post oral test to find out its effectiveness.

\section{Results and Discussion}

Research hypothesis 1: There is a statistically significant difference between the mean scores of the experimental group in the pre and post application of the English oral communication skills test in favor of the post application.

In order to test the previous hypothesis, $\mathrm{T}$ Test was used, SPSS Version 20. T Test for dependent groups was conducted to evaluate the differences between the means of the experimental group on the pre-post applications of the Oral Communication Test. The results for testing this hypothesis are shown in table 1.

Table 1 The t-values of the experimental group students on the post Oral Communication Skills Test

\begin{tabular}{|c|c|c|c|c|c|c|c|c|}
\hline \multirow{2}{*}{$\begin{array}{l}\text { The Sample } \\
\text { The Deviation }\end{array}$} & \multicolumn{6}{|c|}{ Application } & \multirow[b]{2}{*}{ T Value } & \multirow{2}{*}{$\begin{array}{l}\text { Level of } \\
\text { Sign. }\end{array}$} \\
\hline & \multicolumn{3}{|c|}{ Pre } & \multicolumn{3}{|c|}{ post } & & \\
\hline Verbal Skills & 30 & 28.4 & 7 & 30 & 43.2 & 9.8 & 13.3 & 0.01 \\
\hline Non- verbal Skills & 30 & 8.1 & 3.3 & 30 & 11.4 & 4.2 & 7.9 & 0.01 \\
\hline
\end{tabular}






Results shown in table 1 reveal that there is a statistically significant difference between the mean scores of the experimental group students in the pre - post Oral Communication Skills Test applications in favor of the post application. The mean scores of the verbal skills of the experimental group students in the post application which reached 43.2 is bigger than the mean scores of the experimental group students in the pre- application which reached 28.4 . Also, the mean scores of the non-verbal skills of the experimental group students in the post application which reached 11.4 is bigger than the mean scores of the experimental group students in the pre- application which reached 8.1.

Research hypothesis 2: There is a statistically significant difference between the mean scores of the control and experimental groups in the post oral communication skills test in favor of the experimental group.

In order to test the previous hypothesis, T Test was used, SPSS Version 20. T Test for independent groups was conducted to evaluate the differences between the means of both the experimental and control groups on the post application of the Oral

Communication Test. The results for testing this hypothesis are shown in table 2. Which indicate that there is a statistically significant difference at the level 0.01 between the mean scores of the control and experimental groups in the post oral communication skills test in favor of the experimental group.

Table 2 The mean scores, the deviations and $\mathrm{T}$ Values of the post application for the control and experimental groups on the Oral Communication Skills Test

\begin{tabular}{|c|c|c|c|c|c|c|c|c|}
\hline \multirow{3}{*}{$\begin{array}{l}\text { Sample } \\
\text { The } \\
\text { Deviation }\end{array}$} & \multicolumn{6}{|c|}{ Post Application } & \multirow{3}{*}{$\begin{array}{l}\mathbf{T} \\
\text { Value }\end{array}$} & \multirow{3}{*}{$\begin{array}{l}\text { Level } \\
\text { of } \\
\text { Sign. }\end{array}$} \\
\hline & \multicolumn{3}{|c|}{ Experimental } & \multicolumn{3}{|c|}{ Control } & & \\
\hline & $\mathbf{n}$ & mean & Deviation & $\mathbf{n}$ & mean & Deviation & & \\
\hline Verbal Skills & 30 & $\varepsilon r . Y$ & 9.1 & 30 & MY.Y & $1 \cdot . \wedge$ & $\varepsilon .1$ & $\because \cdot 1$ \\
\hline Non- verbal Skills & 30 & 11.8 & $\varepsilon . r$ & 30 & 9.1 & 1.9 & 1.9 & $\because 1$ \\
\hline
\end{tabular}


In addition, results shown in table 2 reveal that the mean scores of the verbal skills of the experimental group students which reached 43.2 at the level of significance 0.01 is bigger than the mean scores of the verbal skills of the control group students which reached 10.8 at the level of significance 0.01 in the post application of the Oral Communication Skills Test. Also, the mean scores of the non-verbal skills of the experimental group students which reached 11.4 at the level of significance 0.01 is bigger than the mean scores of the non- verbal skills of the control group students which reached 1.9 at the level of significance 0.01 in the post application of the Oral Communication Skills Test. The following figure 4.2 points out the differences between the mean scores of the experimental group students and the control group students in the post application of the Oral Communication Skills Test.

These results are consistent with the results of other studies that affirmed the important impact of project-based learning in developing students' EFL different skills. Shehata (2015) stated the effectiveness of using PBL integrated with ICT in enhancing the oral skills of 50 pupils in the second year preparatory School, Minia governorate. Also, Maulany (2013) confirmed the effectiveness of PBL in developing young learners' speaking skill. Furthermore, Ali and El-Henawy (2015) proved the effectiveness of project-based learning on developing student's oral performance where PBL provided them with opportunities to use the English language contextually and creatively in a motivating, challenging and motivating atmosphere. Moreover, Ravitz, Hixson, English and Mergendoller (2012) affirmed the great effect of PBL professional development and implementation on teachers' perceived ability to teach and assess 21 st century skills including critical thinking skills, collaboration skills, communication skills, etc.

The effect of using PBL in developing first year of secondary stage students' oral communication skills that the experimental group students achieved may be due to some reasons. Nevertheless, the first author as a teacher asked her students to choose the topics of the projects they implemented which 


\section{الجمعية المصرية للقر اعة والمعرفة عضو الجمعية الدولية للمعرفة ILA}

were related to their interests such as acting Oliver Twist play, designing a survey on how students prepare for exams and debating on living in the city or countryside. Also, they reflected on their experience and how they benefited from participating in such projects.

In addition, the students' oral communication skills were improved gradually during the implementation of the three projects. They got rid of their reluctance to participate and communicate orally with each other. For example, after finishing the rehearsals of the first project which was acting Oliver Twist play, the students presented it on the theatre of Egypt Library in Port Said. They invited the school administration, and some of the educational officials in the governorate, the parents and the school students to attend the play. They felt that they were using English for authentic reasons as they performed the play in front of a real audience. As for the second project, the students presented the results of the survey on the school broadcast and uploaded them on the school page on Face Book. In addition, they debated whether to live in the city or the countryside. The students enjoyed participation in the three projects and their English communication skills were developed.

As for the second project, they students interviewed some professors of educational psychology to ask them about the best ways of preparing for and memorizing information before exams. After that, they worked in groups to design a survey in the light of the results of the interview. Then, they distributed the survey on the school students. Then, they announced the result of the survey on the school English Broadcast. In addition, they made a debate on which is better to live in the city or countryside. The debate was recorded. So, the teacher and the students could recognize the development of their oral communication skills through the evaluation of these projects.

Moreover, $\mathrm{PBL}$ is collaborative rather than competitive; the projects that were implemented in this study depended on the collaborative work of the students. The students worked on individually, in small groups, or as a class to finish a project. Through the teacher's observation, the students enjoyed their performance during the implementation of the three projects where there were some tasks they had to do inside the classroom and there were other tasks they had to do outside the class. They visited the faculty of Education to implement the second project and to interview two of the psychology professors. They were highly motivated to finish their projects. 


\section{Calculating Effect Size}

The effect size of using the Project-based Learning in

developing the oral communication skills on the first year of

secondary stage students was calculated using the following

formulas (Mansour, 1997, p.73) and results are shown in table 3.

$-2=\eta$

$\mathrm{t} 2+\mathrm{df}$

$2 \eta \sqrt{ } 2$

$\overline{2 \eta \sqrt{ }} 1-$

Table. 3 The Independent Variable, Dependent Variable Value and the Effect Size of Using the Project-Based Learning in Developing the Oral Communication Skills

\begin{tabular}{|l||l|l|l||l|l||l||}
\hline $\begin{array}{l}\text { Independent } \\
\text { variable }\end{array}$ & $\begin{array}{l}\text { Dependent } \\
\text { variable }\end{array}$ & $\begin{array}{l}\text { T } \\
\text { value }\end{array}$ & Df & $\boldsymbol{\eta}^{2}$ & $\begin{array}{l}\text { "d" } \\
\text { Value }\end{array}$ & $\begin{array}{l}\text { Effect } \\
\text { Size }\end{array}$ \\
\hline \hline \multirow{2}{*}{$\begin{array}{l}\text { Project-based } \\
\text { Learning }\end{array}$} & Verbal Skills & 13.3 & $\uparrow q$ & $\ddots \wedge \uparrow$ & 3.5 & Strong \\
\cline { 2 - 7 } & $\begin{array}{l}\text { Non-verbal } \\
\text { Skills }\end{array}$ & 7.9 & $\uparrow ৭$ &.$\Upsilon \uparrow$ & 2.1 & Strong \\
\hline
\end{tabular}

The previous table shows that the effect size for the independent variable (project- based learning) on the dependent variable (oral communication skills) is strong because the $d$ value of the effect size are bigger than 0.8 whereas the effect size for each of dependent variables is due to the strong effect of using the projectbased learning in developing the oral communication skills (verbal and non-verbal skills) of the first year of the secondary stage students.

\section{Conclusion}

The study set out to investigate the effectiveness of using project-based learning in developing the oral communication skills of the first year of secondary stage students. PBL has a great effect on developing first year of secondary stage students' English oral communication skills. In fact, PBL is a pedagogical method focused 
on the learner where he/she is the center of the learning process and teacher has the role of a facilitator and a supporter while practising project-based learning activities. Project-based learning motivates and empowers the students to increase their confidence, self-esteem, and autonomy. The results suggest several possibilities for future studies of English oral communication skills and project-based learning. Replicating the present study on a larger sample that belongs to different schools. Further research is needed to find out the effect of other programs based on project-based learning on developing students' English skills. A variety of measures are needed to evaluate students' English oral communication skills. Conducting a study that investigates attitudes and perceptions of the teachers towards the importance of developing English oral communication skills. It would be beneficial to make further studies on training teachers how to teach students oral communication skills.

\section{References}

Abd El- kader, S. (2018) The Effect of Using some Kinesthetic Activities on Developing EFL Language Performance for the Primary Governmental Language Stage Students. Unpublished doctoral dissertation Faculty of Education. Ain Shams University

Abd El-khaleq, A. (2018) Compensation Strategies for Overcoming EFL Young Learners' Oral Communication Difficulties. Unpublished doctoral dissertation. Faculty of Education. Fayoum University.

M. \& El-henawy, W. (2015). Using Project-Based Learning for Developing Ali, English Oral Performance: A Learner-Friendly Model. The 2nd International Conference, Faculty of Education, Port Said University (18-19), April, 2015 "Towards a Child-Friendly School ".

AL-Masadeh, A. (2014). The Effectiveness of a Designed Project-Based Program for Teaching Oral Skills to Tenth Grade EFL Students in Jordan and Their Attitudes towards These Skills. Journal of Education and Practice. Retrieved May 27, 2016 from http:// www.iiste.org Amin, I., Aly,M., \& Amin,M. (2011). The effectiveness of using an explicit language learning strategy-based instruction in developing 
secondary school students' EFL listening comprehension skills. (ERIC Document Reproduction Service No: ED527447)

Caspersz, D. \& Stasinska, A. (2015). Can we teach effective listening? An exploratory paper. Journal of University Teaching \& Learning Practice. Retrieved February 10, 2016 from http://ro.uow.edu.au/jutlp/vol12/iss4/2

Castañeda, R. (2013). English Teaching through Project Based Learning Method, In Rural Area. Retrieved June 23, 2016 from http://www.scielo.org.co/

Chelbi, R. (2010). Motivating Students to Perform Better Orally in a Communicative Language Teaching Frame Work. Unpublished Master's thesis .Faculty of Letters and Languages. University of Constantine. People's Democratic Republic of Algeria English, M. \& Kitsantas, A. (2013). Supporting Student Self-Regulated Learning in Problem- and Project-Based Learning. Retrieved May 20, 2016 from http://www. http://docs.lib.purdue.edu/ijpbl Filippatou, D., \& Kaldi, S. (2010). The Effectiveness of Project-Based Learning on Pupils with Learning Difficulties Regarding Academic Performance, Group Work and Motivation. International Journal of Special Education. (ERIC Document Reproduction Service No. EJ890562).

Fragoulis, I. (2009). Project-Based Learning in the Teaching of English as A Foreign Language in Greek Primary Schools: From Theory to Practice. (ERIC Document Reproduction Service No. EJ1083088).

Jung, S. (2011). Demotivating and remotivating Factors in Learning English: A Case of Low Level College Students. Retrieved January 17, 2017 from http://www. journal.kate.or.kr/wpcontent/uploads/2015/01/kate_66_2_3.pdf Kovalyova, Y., Soboleva, A. and Kerimkulov, A. (2016). Project Based Learning in Teaching Communication Skills in English as a Foreign Language to Engineering Students. Retrieved May 7 , 2018 from http://dx.doi.org/10.3991/ijet.v11i04.5416 Khalil, A. (2015). The Effectiveness of a Training Program Based on Instruction Technology on Developing the Listening and Speaking Skills for Faculty of Education English Majors. Unpublished doctoral dissertation. Faculty of Education. Ain Shams University. 
Hamad, M. (2013). Factors Negatively Affect Speaking Skills at Saudi Colleges for Girls in the South. (ERIC Document Reproduction Service No. EJ1078510).

Hietala, M. (2013). Practicing oral skills in Finnish upper secondary school EFL textbooks. Unpublished Master's Thesis. University of

Jyväskylä.

Hassan, S. (2018) The Effect of a Training Program Based on Some Active Learning Strategies on Developing EFL Oral Communication

Skills of 2nd Year Prep School Students. Unpublished Master's thesis. Faculty of Education. Minia University.

Iamsaard, P. \&Kerdpol, S. (2015). A Study of Effect of Dramatic Activities on Improving English Communicative Speaking Skill of Grade 11th Students. (ERIC Document Reproduction Service No. EJ1080285).

Ilter, I. (2014). A paper on the efficacy of project-based learning approach on Social Studies Education: Conceptual achievement and academic motivation. Educational Research and Review. Retrieved June 15, 2015 from http://www.academicjournals.org/ERR Liao, G. (2009). Improvement of Speaking Ability through Interrelated Skills. English Language Teaching. Retrieved February 10, 2016 from http:// www.ccsenet.org/journal.html Maulany, D. (2013). The Use of Project-Based Learning in Improving the Students`Speaking Skill. Journal of English and Education.

Retrieved February 10, 2016 from http://ejournal.upi.edu/index.php/L-E/article/view/323

Morreale, S., Morreale, S. Spitzberg, B., \& Barge, J. (2007). Human Communication: Motivation, Knowledge \& Skills (2nd ed.).

Belmont, CA: Thomson Higher Education.

Peterson, R. \& Leonhardt, J. (2015). The Complementary Effects of Empathy and Nonverbal Communication Training on Persuasion Capabilities. (Eric Document Reproduction Service No. EJ1062482).

Simpson, J. (2011). Integrating Project-Based Learning in an English Language Tourism Classroom in a Thai University. Unpublished dissertation. Faculty of Education. Australian Catholic University.

Soparat, S., Arnold,R. \& Klaysom,S. (2015). The Development of Thai Learners' Key Competencies by Project-based Learning Using 
ICT. International Journal of Research in Education and Science (IJRES). (ERIC Document Reproduction Service ED548501).

Mahmoud, M. (2010). A suggested Technotainment Program for Enhancing the Communication Skills of Primary Students and their Motivation towards Learning English. Unpublished master's thesis Master's thesis, Faculty of Education, Ain Shams University.

Mitry, M. (2009). The Effect of Project-Based Program in Developing Some Technical Writing Genres in English for Applied Arts Students in the Light of Constructivist learning. Unpublished Thesis. Institute of Educational Studies. Cairo University.

Pereira, M., Barretoa,M., Pazetia,M.(2017). Application of Project-Based

Learning in the first year of an Industrial Engineering Program:

lessons learned and challenges. Retrieved May 8, 2018 from www.scielo.br/pdf/prod/v27nspe/0103-6513-prod-27 (spe).e20162238.pdf Plo, R., Horanero,A. \& Mur, P. (2013). Implementing the Teaching/Learning of Oral Skills in Secondary Education in Aragòn: Gauing Teacher's Attitudes, beliefs and Expectations. (Eric Document Reproduction Service No.EJ1042862).

Rahman, M. M. (2010). Teaching Oral Communication Skills: A Task-based Approach. ESP World, 9 (1). Retrieved February 8, 2016 from http://www.esp-world.info

Ravitz, J. Hixson, N., English, M. and Mergendoller, J. (2012). Using project based learning to teach 21 st century skills: Findings from a statewide initiative. Retrieved June 15, 2016 from http:// www.bie.org/images/

Shabaan, R. (2010). The Effectiveness of a Suggested Computer-Based Program for Developing Some EFL Oral Communication Skills among Preparatory School Students. Unpublished master's thesis. Faculty of Education. Banha University. Shehata, A. (2015). The Effectiveness of Using Project Based Learning Integrated with ICT in Developing Second Year Prep-School

Students' Aural- Oral Communication Skills. Unpublished thesis. Faculty of Education. Minia University. Sun,C. (2015). The Cultivation of Cross-cultural Communication Competence in Oral English Teaching Practice. (ERIC Document Reproduction Service No. EJ1084298). 
Subaşı, G. (2010). What are the Main Sources of Turkish EFL Students' Anxiety in Oral Practice? ERIC Document Reproduction Service

N.: ED537842.

Zoric, G., Smid, K., \& Pandzic, I. S. (2007). Facial Gestures: Taxonomy and applications of on-verbal, non-emotional facial displays for embodied conversation agents. In T. Nishida (Ed.), Conversational Informatics: An Engineering Approach. West Sussex: John Wiley \& Sons Ltd.

Zuheer, K. (2008). The Effect of Using a Program Based on Cooperative Learning Strategy on Developing some Oral Communication Skills of Students, at English Department, Faculty of Education, Sana'a University. Unpublished thesis. ERIC Document Reproduction Service N.: ED502845 